\title{
INTEGRATED CONTINUOUS CARE: COLLABORATING WITH THE ELDERLY FUNCTIONALITY
}

\author{
CUIDADO CONTÍNUO INTEGRADO: COLABORANDO PARA A \\ FUNCIONALIDADE DO IDOSO
}

\author{
Mariana Bogoni BUDIB ${ }^{1}$; Marilena Infiesta ZULIM² ${ }^{2}$ Vanessa MARCON DE OLIVEIRA ${ }^{1}$; \\ Vanessa Terezinha Gubert de MATOS ${ }^{1}$ \\ 1. Universidade Federal de Mato Grosso do Sul, Campo Grande, MS, Brasil; 2. Hospital São Julião, Campo Grande, MS, Brasil. \\ marianabudib@hotmail.com
}

\begin{abstract}
This study aimed to evaluate the influence of Integrated Continuous Care on the functional independence of the elderly. This cohort study included participants aged 60 years or older who had experienced a disabling event or disease, and were admitted to rehabilitation in a Brazilian Integrated Continuous Care Unit. The functional gain was evaluated by the Barthel index. Fifty-nine elderly individuals admitted due to a disabling event or disease at the ICCU were assisted from March 2014 to February 2015. Since twenty-two of these were excluded, only 37 participants were evaluated. The mean age of the elderly that were included was 70.41 years $( \pm 1.40)$ and most of them presented an ischemic stroke diagnosis $(64.9 \%)$. The total functional gain was $24.05( \pm 3.84)$ points, with an average stay of $32.32( \pm 2.18)$ days. When compared with the degree of dependence on the admission and at discharge, total or severe dependence was identified in $62.2 \%$ on admission and mild dependence or total independence was identified in $54.1 \%$ at discharge, with a significant decrease in the percentage of the elderly with total dependence between admission and discharge (McNemar test, $\mathrm{p}=0.001$ ). At hospital discharge, $70.3 \%$ of the elderly had better individual performance in their Activities of Daily Living than at hospital admission and none of them got worse. The multi-professional team-based approach in the Integrated Continuous Care assistance model favors the elderly with gain in functionality and independence. The social network involvement of the elderly lead to their empowerment and co-responsibility along with their family/caregiver in pursuit of the therapeutic goals established together.
\end{abstract}

KEYWORDS: Activities of Daily Living. Aging. Patient Care Planning. Professional Practice. Rehabilitation Research. Treatment Outcome.

\section{INTRODUCTION}

Aging is a natural process involving the cumulative, irreversible, universal, non-pathological deterioration of a mature organism (ARKING, 1999), which includes decreased muscle strength, flexibility and balance (HERNANDES et al., 2013). These changes affect functionality, that is defined as the ability of an individual to manage their life or take care of themselves (WHO, 2001), and it can lead the person to be dependent (KAGAWA; CORRENTE, 2015). There were 267,076 elderly in the state of Mato Grosso do Sul in 2014, while there were almost 23 million in Brazil in the same year (BRASIL, 2019).

Older people are more likely to be affected by chronic non-communicable diseases (NCDs) compared to healthy adults (WHO, 2014). These diseases include cardiovascular conditions (mainly heart disease and stroke), some cancers, chronic respiratory conditions and type 2 diabetes (DAAR et al., 2007). Chronic non-communicable diseases can lead to incapacity, decreased functional independence level, and permanent or long-term state of partial or total physical dependence (MUKA et al., 2015). Usually, these conditions tend to affect the quality of life among the elderly significantly that may compromise their self-esteem, self-image, and relationship with their families and society (SCHMIDT et al., 2011).

No single organization or sector can therefore solve the problem alone. The engagement of the whole of government and whole of society is necessary to support countries to reduce NCDs. It means multi-sector collaboration of the health sector, non-profit organizations, schools, businesses, and other governmental agencies, including transport, planning, and education (WHO, 2017). In the Central West of Brazil, an Integrated Continuous Care Unit (ICCU) was implemented to adjust local health system to the new scenario, through public, social partnerships with international institutions. This model of assistance has begun in 2013 in four Brazilian states, and there are few national studies published on the theme. 
The Hospital São Julião started its activities using the ICC model in October 2013 in Campo Grande, MS. The other institutions that adhered to the Project are located in Rebouças (state of Paraná), Ipuã and Pedregulho, both in the state of São Paulo. The Hospital de São Carlos Barromeu in Teresina (state of Piauí) gave up the implementation of ICC in their hospital.

In general, the elderly arrives at the ICCU referred to some unit of high complexity and is received by all members of the multidisciplinary team that will take care of the elderly (Figure 1). During this first contact, the host and professionals perform qualified listening. Then each professional has a period of 48 hours to perform their specific clinical evaluation and together with the caregiver and the elderly the Singular Therapeutic Project (STP) is traced. In the construction of STP, the staff, family/caregiver and the elderly assemble the care strategies, define a period of hospitalization, and promote the joint continuity of care and the health care networks.

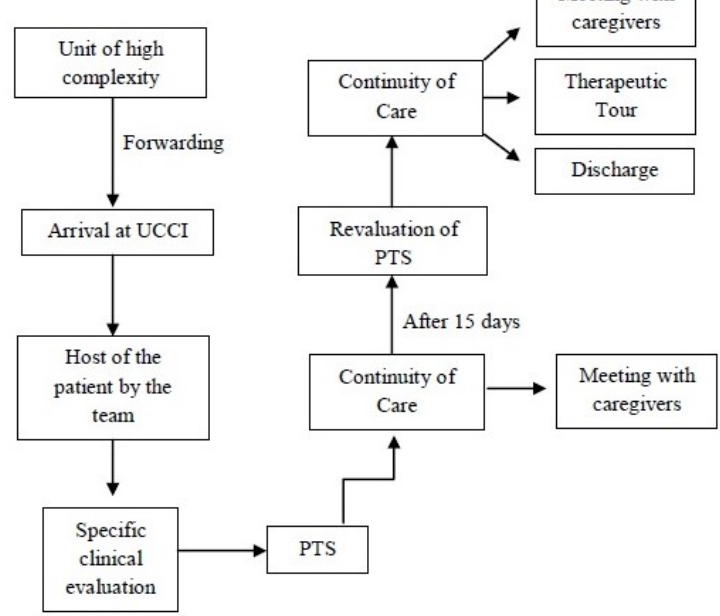

Figure 1. Illustration of patient flow from arrival to discharge of the Integrated Continuing Care Unit.

The rehabilitation program is designed according to the individual needs of the elderly and the treatment to be performed is described in the STP. Thus, elderly receives daily visits from doctors, nurses, a physiotherapist, nutritionist, clinical pharmacist, social worker and psychologist. Sessions of occupational therapy, speech therapy, and dentistry are performed twice a week. So the elderly receives specific interventions from each professional, along with guidance and training regarding the continuity of home care.

STP is reevaluated every 15 days to identify the results and reprogramming or permanence of goals and deadlines. Once a week, a meeting is held with caregivers in order to ask questions and share experiences in common about a theme suggested by them. The objective of establishing the joint STP is to promote programed and organized discharge defined as transfer of care. It is conducted in a secure way with guidance to elderly and families, strengthening the autonomy of the subject and continuity of care.

Another developed activity is the "therapeutic tour". At this time, elderly and caregivers have the experience of domestic care during weekends and can put into practice the learning received at the ICCU. After the weekend, they return to solve doubts that arose during the period. However, it is important to report that the "therapeutic tour" usually happens near the time of discharge and always after training and agreement with the entire team.

Integrated Continuous Care is a rehabilitation assistance that aims to continue the treatment for people with dependence after hospital discharge. The multi-professional assistance searches improvements to the access of the citizen in fragility situations, functionality promotion, prevention and reduction of disability. The professions that form the multi professional staff of the ICC in the Central West of Brazil are medicine, physical therapy, occupational therapy, speech therapy, nutrition, social work, nursing, psychology, dentistry and pharmacy. ICC is also conducted in the field of in-service training for Multi-professional Interns in the Integrated Continuous Care - Area of concentration: Health of the Elderly.

Thus, the objective of this study was to evaluate the influence of the ICC on the functional 
independence of the elderly assisted by a multiprofessional team.

\section{MATERIAL AND METHODS}

\section{Study design}

Retrospective cohort study

\section{Study location}

This study was carried out at the ICCU of the Hospital São Julião in the capital of Mato Grosso do Sul, Central West of Brazil. It is one of the four ICCUs in Brazil, which were developed as a project by the Confederação das Santas Casas de Misericórdias, Hospitais e Entidades Filantrópicas with the support of the Brazilian Ministry of Health.

\section{Study population}

Participants were identified through the hospital system, and included those who aged 60 years or older, admitted from March 2014 to February 2015 at the ICCU, due to, recent functional dependence, need for nursing care, need for rehabilitation, secretion aspiration, need for nasogastric tube feeding, need for ulcer and wound care, presence of stoma, need for parenteral administration, need for oxygen, presence of stable chronic disease with high risk of decompensation, transitory loss of potentially recoverable autonomy and availability of a caregiver. The indigenous and Quilombola people, and/or individuals deprived of their liberty were excluded.

\section{Data collection}

Data were collected from medical records, which included socio-demographic data, health social determinants (age, gender, education, physical activity, and income), comorbidities, length of hospital stay, main diagnosis and the scores on the Barthel Index for admission and discharge.

The Barthel Index evaluates the individual's performance on his Activities of Daily Living (ADL) and it measures the functional independence as feeding, grooming, bathing, dressing, bowel and bladder care, toilet use, ambulation, transfers, and stair climbing.

The purpose of the Barthel Index is to monitor and quantify the level of functional independence. It is a low cost scale, which can easily and periodically be applied, and it is the most widely used tool to evaluate the performance of the ADL.

The score is given according to the performance of the requested tasks, either independently or with help. The overall score is the sum of each category in points on a scale from 0 to 100, where the higher scores indicate greater independence (MINOSSO et al., 2010). In this study, the points were considered as follows: $<20$ corresponds to total dependence, from 20 to 40 points for severe dependence, 45 and 60 points to moderate dependence, $>60$ for light dependence, and 100 points for full independence.

\section{Data analysis}

McNemar test was used to evaluate the association between the severity of dependence during hospital admission and hospital discharge, by the Barthel Index. The comparison between the time of admission and of discharge, in relation to partial scores on each item and the total score of the Barthel Index was performed by the Wilcoxon test, since the samples failed the Shapiro-Wilk normality test. Finally, the comparison between the variations of age, gender, marital status, schooling, family income, origin, comorbidities, lifestyle and length of hospital stay, compared with the gain in the Barthel Index between hospital admission and discharge, was performed using the Kruskal-Wallis test (marital status) or using the Mann-Whitney test (other variables). The other results of this study were presented by descriptive statistics or by tables and graphs. Statistical analysis was performed using the SigmaPlot statistical program version 12.5, considering a 5\% significance level.

\section{Ethics}

Ethical approval for this project was obtained from Ethics Committee of Research of the Federal University of Mato Grosso do Sul (No: 46921315.5.0000.0021) and all participants enrolled in the study provided written informed consent.

\section{RESULTS}

Fifty-nine elderly participants admitted due to a disabling event or disease at the ICCU were assisted from March 2014 to February 2015. Twenty-two of these were excluded, nine due to lack of data in the medical records, seven because they had not completed the period of hospitalization, and six due to death during hospitalization. Thus, 37 participants were evaluated, ranging from 60 to 92 years of age, with mean age of $70.41 \pm 1.40$ years (mean \pm standard error of the average).

The primary diagnosis for most of them was ischemic stroke $(24 / 37 ; 64.9 \%)$. Hypertension $(21 / 37 ; 56.8 \%)$, diabetes $(9 / 37 ; 24.3 \%)$, heart disease $(12 / 37 ; 32.4 \%)$, dyslipidemia $(5 / 37 ; 13.5 \%)$ and other comorbidities $(11 / 37 ; 29.7 \%)$ were also 
identified. The modifiable risk factors such as smoking $(14 / 37 ; 37.8 \%)$ and alcohol consumption $(6 / 37 ; 16.2 \%)$ were observed as well as a small number of elderly reporting regular physical activity $(1 / 37 ; 2.7 \%)$. The length of hospital stay for the elderly ranged from 10 to 60 days and the average length of stay was $32.32 \pm 2.18$ days. Most of them remained hospitalized for 30 days $(59.5 \%$; 22/37).

Among the professions reported by the elderly, domestic worker was the most frequent $(11 / 37 ; 19.7 \%)$, followed by rural workers and housewives $(7 / 37 ; 18.9 \%)$, and bricklayers $(4 / 37$; $10.8 \%)$. Each of the remaining $5.4 \%(2 / 37)$ reported to be retired, general services workers, hairdressers, and tailors.
Upon comparing the degree of dependence on admission with that at discharge, total or severe dependence was identified in $62.2 \%(23 / 37)$ of participants on admission and mild dependence or total independence was identified in 54.1\% (20/37) at discharge, with a significant decrease in the percentage of those with total dependence between admission and discharge (McNemar test, $\mathrm{p}=0.001$ ). Therefore, there was an increase in the percentage of the elderly with mild dependence between admission and discharge $(\mathrm{p}=0.009)$ (Figure 2). At hospital discharge, $70.3 \%(26 / 37)$ of the elderly had better individual performance on their Activities of Daily Living (ADL) than at hospital admission and none of the elderly got worse.

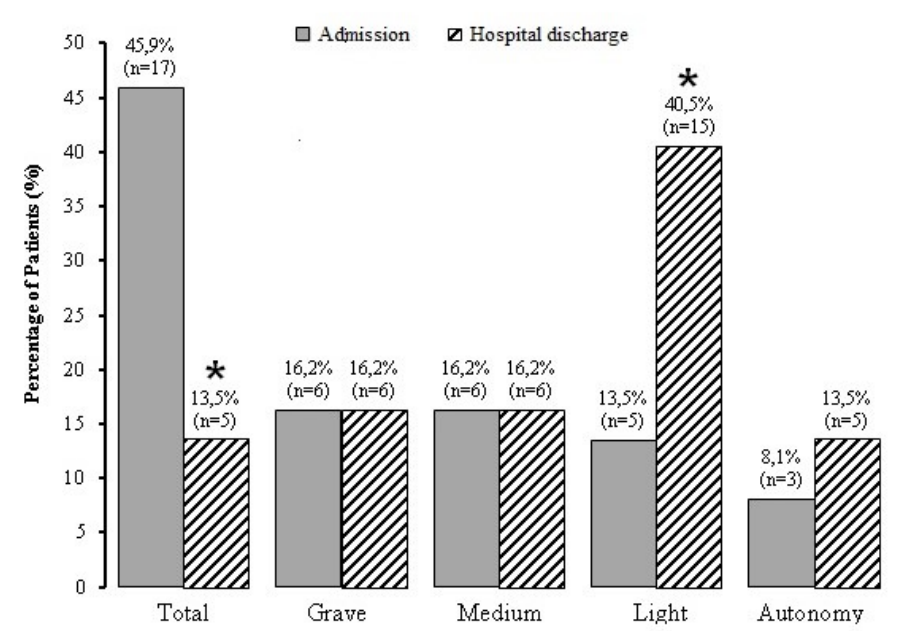

Figure 2. Graph showing the percentage of patients according to the degree of dependence by the Barthel Index at the time of admission at discharge.

*Significant difference in relation to the time of admission (meNemar test, $\mathrm{p}<0,050$ ).

The Brazilian minimum wage during the period of the study was established between R\$ 724.00 and $\mathrm{R} \$ 788.00$ (Reais, Brazilian currency) which is equivalent to $\$ 289.6$ and $\$ 262.66$ (American Dollar). Factors such as age, sex, marital status, education, family income, origin, comorbidities, life style and length of hospital stay have not influenced the functionality, since no differences were observed between the variations of these variables (Kruskal-Wallis test or MannWhitney test, $p$ value ranging from 0.217 and 0.960 ) (Table 1).

The same was observed in relation to the total index, which increased from $32.03 \pm 5.20$ points (severe dependence) on the admission to $56.08 \pm 5.01$ points (moderate dependence) at the discharge $(p<0.001)$. In general, there was an average gain of $24.05 \pm 3.84$ points in the functionality of the elderly between the admission and at the hospital discharge (Figure 3).

With the exception of bathing and grooming, the scores of the Barthel Index increased significantly between admission and discharge (Wilcoxon test, $\mathrm{p}$ values ranging from $<0.001$ to 0.002 ), which characterize the improvement of the functionality (Table 2).

In the elderly with ischemic stroke, there was a considerable gain, since $62.5 \%(15 / 24)$ had total dependence at the time of admission and almost the same proportion $(14 / 24,58.3 \%)$ was identified with mild dependence or independence at hospital discharge. 
Integrated continuous...

BUDIB, M. B. et al.

Table 1. Comparison between characteristics of the elderly and hospital stay related to the gain of Barthel Index between ICCU admission and ICCU discharge.

\begin{tabular}{|c|c|c|c|}
\hline Variable/variation & $\mathrm{n} / \%$ & $\begin{array}{l}\text { Score Gain } \\
(\text { mean } \pm \text { MSE) }\end{array}$ & $P$ value \\
\hline \multicolumn{4}{|l|}{ Sex } \\
\hline Male & $23 / 62.2$ & $25.43 \pm 4.99$ & \\
\hline Female & $14 / 37.8$ & $21.79 \pm 6.15$ & 0.632 \\
\hline \multicolumn{4}{|l|}{ Marital Status } \\
\hline Married or Stable union & $15 / 40.5$ & $30.33 \pm 6.14$ & \\
\hline Separated or divorced & $7 / 18.9$ & $22.86 \pm 6.25$ & \\
\hline Widow & $10 / 27.0$ & $15.00 \pm 7.89$ & \\
\hline Single & $1 / 2.7$ & $13.75 \pm 6.25$ & 0,227 \\
\hline \multicolumn{4}{|l|}{ Education } \\
\hline Up to complete Primary School & $34 / 91.9$ & $22.35 \pm 3.66$ & \\
\hline High School up to complete undergraduate & $3 / 8.1$ & $43.33 \pm 23.51$ & 0.293 \\
\hline \multicolumn{4}{|l|}{ Family income } \\
\hline Up to 1 (minimum wages) & $15 / 40.5$ & $23.33 \pm 7.38$ & \\
\hline Over 1 (minimum wages) & $22 / 59.5$ & $24.55 \pm 4.20$ & 0.658 \\
\hline \multicolumn{4}{|l|}{ Origin } \\
\hline Campo Grande & $27 / 73.0$ & $25.93 \pm 5.16$ & \\
\hline Other places is & $10 / 27.0$ & $19.00 \pm 2.45$ & 0.96 \\
\hline \multicolumn{4}{|l|}{ HAS } \\
\hline No & $16 / 43.3$ & $17.81 \pm 5.30$ & \\
\hline Yes & $21 / 56.7$ & $28.91 \pm 5.29$ & 0.217 \\
\hline \multicolumn{4}{|l|}{ Diabetes } \\
\hline No & $28 / 75.7$ & $24.64 \pm 4.64$ & \\
\hline Yes & $9 / 24.3$ & $16.25 \pm 3.50$ & 0.234 \\
\hline \multicolumn{4}{|l|}{ Heart disease } \\
\hline No & $25 / 67.6$ & $21.00 \pm 4.08$ & \\
\hline Yes & $12 / 32.4$ & $30.42 \pm 8.20$ & 0.296 \\
\hline \multicolumn{4}{|l|}{ Dyslipidemia } \\
\hline No & $32 / 86.5$ & $22.97 \pm 3.70$ & \\
\hline Yes & $5 / 13.5$ & $31.00 \pm 16.91$ & 0.949 \\
\hline \multicolumn{4}{|l|}{ Smoking } \\
\hline No & $23 / 62.2$ & $25.87 \pm 5.01$ & \\
\hline Yes & $14 / 37.8$ & $21.07 \pm 6.07$ & 0.567 \\
\hline \multicolumn{4}{|l|}{ Alcohol use } \\
\hline No & $31 / 83.8$ & $23.71 \pm 4.23$ & \\
\hline Yes & $6 / 16.2$ & $25.83 \pm 9.87$ & 0.888 \\
\hline \multicolumn{4}{|l|}{ Hospital stay } \\
\hline Up to 30 days & $22 / 59.5$ & $22.50 \pm 5.07$ & \\
\hline Over 30 days & $15 / 40.5$ & $26.33 \pm 6.01$ & 0.593 \\
\hline
\end{tabular}




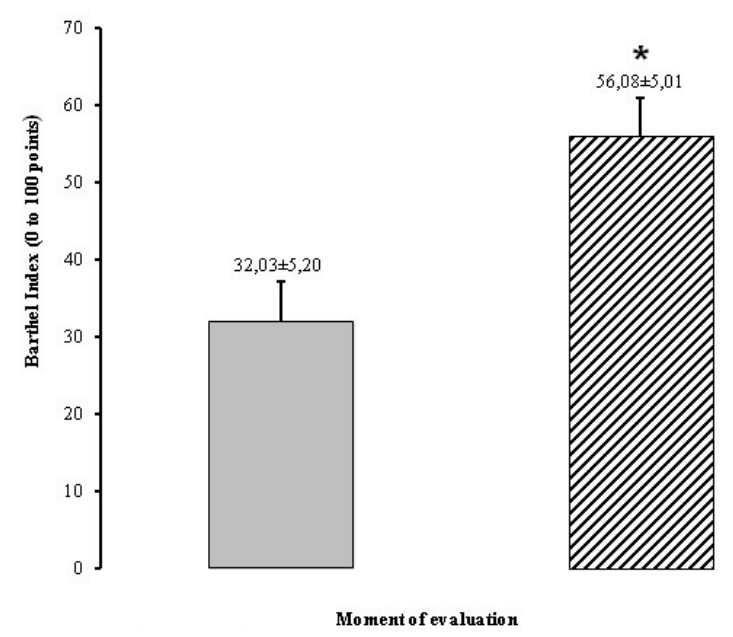

Figure 3. Graphic presenting the Barthel Index, at the hospital admission and at the hospital discharge. *Significant difference in relation to the hospital admission (Wilcoxon test, $\mathrm{p}<0,001$ ).

Table 2. Scores of Barthel Index for each dimension as well as the total Index evaluated at the ICCU admission and discharge for the elderly

\begin{tabular}{llll} 
Dimension & $\begin{array}{l}\text { Moment } \\
\text { Admission }\end{array}$ & Discharge & P value \\
\hline Feeding & $3,38 \pm 0,61$ & $7,57 \pm 0,57$ & $<0,001$ \\
Bathing & $1,22 \pm 0,41$ & $1,62 \pm 0,39$ & 0,375 \\
Dressing & $3,65 \pm 0,50$ & $5,27 \pm 0,43$ & 0,002 \\
Grooming & $2,30 \pm 0,50$ & $3,11 \pm 0,40$ & 0,129 \\
Bowels & $5,00 \pm 0,72$ & $7,43 \pm 0,60$ & $<0,001$ \\
Bladder & $3,92 \pm 0,75$ & $6,08 \pm 0,65$ & 0,001 \\
Toilet use & $2,84 \pm 0,63$ & $5,68 \pm 0,55$ & $<0,001$ \\
Transfers & $4,32 \pm 0,83$ & $8,24 \pm 0,83$ & $<0,001$ \\
Mobility & $2,84 \pm 0,81$ & $6,35 \pm 0,94$ & $<0,001$ \\
Stairs & $1,65 \pm 0,52$ & $5,27 \pm 1,64$ & $<0,001$ \\
Total Score & $\mathbf{3 2 , 0 3} \pm \mathbf{5 , 2 0}$ & $\mathbf{5 6 , 0 8} \pm \mathbf{5 , 0 1}$ & $<\mathbf{0 , 0 0 1}$ \\
\hline
\end{tabular}

The results are presented in the means \pm error of the mean pattern. P-value on Wilcoxon test.

The median score on the Barthel Scale at the time of admission of the elderly was 30 points (interquartile interval $=40$; severe dependence from 20 to 35), the median score was 65 points (interquartile interval $=50$; mild dependence from 60 to 95)at the time of discharge. There was a significant gain of independence between admission and discharge (Wilcoxon signed rank test, $\mathrm{p}<0.001$ ).

\section{DISCUSSION}

Corroborating with our results, previous studies have observed an increase in the number of men with functional decline (BLANCA GUTIÉRREZ et al., 2009; STHAL et al., 2011) as well as a low educational level among the geriatric population (STHAL et al., 2011), which seems to justify the family income observed among the participants. The low income seems to be associated with professions/occupations that do not require high levels of education. Confirming this finding, the predominant professions in this study were household workers, rural workers, and bricklayers.

Although the literature reports the direct association between socio demographic variables (STUCK et al., 1999; STHAL et al., 2011; BAHAT et al., 2014; KUMAR et al., 2014) and comorbidities (STUCK et al., 1999; BAHAT et al, 2014) of functionality, this research has not found a significant association between these variables. Probably, this result is due to the ICC assistance model that considers the bio psychosocial aspects of the elderly.

According to the Country Ministry of Health (BRASIL, 2013), stroke is the first cause of death and disability in Brazil. Therefore, age and population aging are risk factors for its occurrence, which supports the data of this study. Physical 
disability, even if it is not permanent, can be challenging in situations that compromise physical and psychological aspects. This causes limitations and changes that both affect the quality of life of the elderly, their caregivers and family (SCHMIDT et al., 2011). The ICC model seeks to reduce these limitations and changes. ICC is defined as "a set of sequential health interventions and/or social support, resulting from joint assessment focused on the global recovery understood as the therapeutic process and social, active and ongoing support, which aims to promote the autonomy and improve the functionality of the person in a dependent situation, through the family and social rehabilitation, readjustment and reintegration" (NATIONAL NETWORK CARE CONTINUUM INTEGRATED, 2013).

Co-responsibility is a fundamental part in the rehabilitation process because it provides the establishment of closer ties, and allows the elderly to understand their responsibility so that their treatment can progress properly (GIRÃO et al., 2017; VOSECKOVA et al., 2017). Another aspect that strongly contributes to the elderly coresponsibility and ease of care after discharge is "Therapeutic Walking". This walking is conducted during hospitalization in a systematic way, where the participant goes home on Saturday and returns to the ICCU on Sunday night. During the therapeutic walking weekend, the family and the elderly work together on the guidelines received at ICC and report the greatest difficulties they faced when they return. The difficulties are managed through new guidelines and training to identify the need for any physical structure adjustment at the residence.

This study shows that the elderly who attended the ICC model presented significant improvement in functionality. Regarding improvement on the items of the Barthel Index, the elderly presented significant improvement in most of items, except bathing and grooming. These findings are similar to the results presented by Morone et al., (2015) who also described the low levels of functional gain in these two modalities. These results can be attributed to the combination of several factors, including the fact that most of the subjects included in this study were mainly diagnosed with stroke. According to Morone et al. (2015), individuals who had a stroke are unlikely to regain independence for bathing and personal hygiene; however, they are highly likely to become independent for bowel and bladder functions and have a median probability of regaining independence in transfers and mobility. According to Kong and Lee (2014), bathing requires a longer period of recovery owing to the complexity of the activities involved. Thus, considering the neurological impairment and the complexity of bathing and personal hygiene tasks, it is expected that these participants present a lower score in their respective items in the Barthel Index. Another factor that could contribute to these results is that the Barthel Index contains only two possible scores for bathing (dependent or independent) and for grooming (able or unable). The low sensitivity of these two sub-scores may have contributed to these results.

Most of the elderly have moved from severe to mild dependence, with a significant increase in the total score of the Barthel Index between admission and discharge and a significant increase in the average improvement. In a study held in a rehabilitation center for the elderly in Madrid that included an occupational therapist, physical therapist, physician, speech therapist, nurse, and social worker, similar results were described with a mean increase of 29.71 points (BAZTAN et al., 2004). In another survey (BLANCA GUTIÉRREZ et al., 2009) that aimed to reduce the functional dependence index of participants through nursing practice, the average increased by 5.94 points. Thus, the role of multi-professionals in the care of the elderly with impaired functionality seems to result in greater independence and functional gain when compared to the performance of a single professional category.

\section{Strengths and limitations}

The empowerment and co-responsibility of the elderly and their family/caregivers regarding therapeutic goals were major strengths of the study, but there are some limitations as well. First, the number of elderly participants in this model of care was relatively small, but occurred since ICC is a recent project in Brazil. It would be interesting to conduct further research to consolidate the significant results found in this study. Second,-the lack of information in medical records during data collection has led to the exclusion of $15 \%$ of the elderly, a factor that could be avoided by adopting more effective record measures.

\section{CONCLUSION}

Our study offers unique data on the positive influence of the ICC on the functional independence of the elderly in Brazil. In this model, the elderly benefits from the multi-professional team-based approach and the interaction between the various areas of health. Additionally, the interaction 
between the participants and their social network lead to their empowerment and co-responsibility along with that of their family/caregivers in pursuit of the therapeutic goals established together.

RESUMO: Investigar a influência dos Cuidados Continuados Integrados na independência funcional de idosos. Este estudo de coorte incluiu participantes com 60 anos ou mais que sofreram algum evento ou doença incapacitante e que foram internados para reabilitação em Unidade Brasileira de Cuidados Continuados Integrados. O ganho funcional foi avaliado pelo índice de Barthel. Cinquenta e nove idosos admitidos por um evento ou doença incapacitante na UCCI foram atendidos de março de 2014 a fevereiro de 2015. Como vinte e dois deles foram excluídos, apenas 37 participantes foram avaliados. A média de idade dos pacientes incluídos foi de 70,41 anos $( \pm 1,40)$ e a maioria apresentou AVC isquêmico como diagnóstico (64,9\%). O ganho funcional total foi de 24,05 $( \pm 3,84)$ pontos, com tempo médio de permanência de 32,32 $( \pm 2,18)$ dias. Quando comparados o grau de dependência na admissão e na alta, a dependência total ou grave foi identificada em $62,2 \%$ na admissão e a dependência leve ou independência total foi identificada em 54,1\% na alta, com uma diminuição significativa no percentual de pacientes com dependência total entre admissão e alta (teste de McNemar, $\mathrm{p}=0,001)$. Na alta hospitalar, 70,3\% dos pacientes apresentaram melhor desempenho individual em suas Atividades de Vida Diária do que no momento da admissão hospitalar e nenhum paciente piorou. A abordagem multiprofissional baseada em equipe no modelo assistencial do Cuidado Integrado Contínuo beneficia o idoso, com ganho de funcionalidade e independência. O envolvimento do paciente na rede social leva ao empoderamento e corresponsabilidade deste e da família/cuidador na busca dos objetivos terapêuticos estabelecidos em conjunto.

PALAVRAS-CHAVE: Atividades Cotidianas. Envelhecimento. Planejamento da Assistência ao Paciente. Prática Profissional. Pesquisa de Reabilitação. Resultado do Tratamento.

\section{REFERENCES}

ARKING, R. Biology of Aging. 2. ed. Sinauer Associates, Sunderland, Massachusetts, 1999. 570 p.

BAHAT, G.; TUFAN, F.; BAHAT, Z.; TUFAN, A.; AYDIN, Y.; AKPINAR, T. S.; NADIR, A.; ERTEN, N.; KARAN, M. A. Comorbidities, polypharmacy, functionality and nutritional status in Turkish communitydwelling female elderly. Aging Clin Exp Res, v. 26, n. 3, p. 255-9, jun. 2014. https://doi.org/10.1007/s40520014-0229-8.

BAZTAN, J. J.; DOMENEECH, J. R.; GONZÁLEZ, M.; FORCANO, S.; MORALES, C.; RUIPÉREZ, I. Ganancia funcional y estancia hospitalaria en la unidad geriátrica de media estancia del Hospital Central de Cruz Roja de Madrid. Rev Esp Salud Publica, v. 78, n. 3, p. 355-366, may-jun. 2004. Disponível em: < http://scielo.isciii.es/pdf/resp/v78n3/original2.pdf>. Acesso em: 14 dez 2017. https://doi.org/10.1590/S113557272004000300005

BLANCA GUTIÉRREZ, J. J.; CARABALLO NÚÑEZ, M. A.; LUQUE PÉREZ, M.; MUÑOZ SEGURA, R. El aumento de la independencia de los pacientes en el hospital. Enferm Glob, n. 16, jun. 2009. Disponível em: $<$ http://scielo.isciii.es/pdf/eg/n16/clinica3.pdf>. Acesso em: 15 dez. 2017 https://doi.org/10.4321/S169561412009000200004

BRASIL. Ministério Da Saúde. Secretaria de Atenção à Saúde. Departamento de Ações Programáticas Estratégicas. Diretrizes de atenção à reabilitação da pessoa com acidente vascular cerebral. Brasília: Ministério da Saúde, 2013. Disponível em:

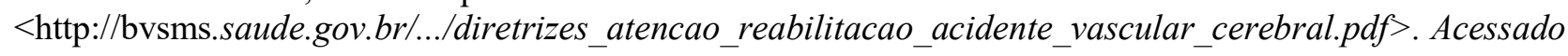
em: $15 \mathrm{dez} .2017$.

BRASIL. Ministério da Saúde. DATASUS. População residente - Estudo de estimativas populacionais por município, idade e sexo 2000 - 2015 - Brasil. Disponível em :

$<$ tabnet.datasus.gov.br/cgi/tabcgi.exe?novapop/cnv/popbr.def $>$. Acessado em 15 de setembro de 2019. 
DAAR, A. S.; SINGER, P. A.; PERSAD, D. H.; PRAMMING, S. K.; MATTHEWS, D. R.; BEAGLEHOLE, R.; BERNSTEIN, A.; BORYSIEWICZ, L. K.; COLAGIURI, S.; GANGULY, N.; GLASS, R. I.; FINEGOOD, D. T.; KOPLAN, J.; NABEL, E. G.; SARNA, G.; SARRAFZADEGAN, N.; SMITH, R.; YACH, D.; BELL, J. Grand challenges in chronic non-communicable diseases. Nature, v. 450, n. 22, p. 494-496, nov 2007. https://doi.org/10.1038/450494a

GIRÃO, A. L, A.; OLIVEIRA, G. Y. M.; FREITAS, R. J. M.; GOMES, E. B.; CARVALHO, R. E. F. L.; FREITAS, C. H. A. Assessment of Treatment For Hypertension In Primary Care. Intern Arch Med, v. 10, n 109, p. 1-12, apr. 2017. https://doi.org/10.3823/2379.

HERNANDES, N. A.; PROBST, V. S.; SILVA JÚNIOR, R. A,; JANUÁRIO, R. S. B.; PITTA F.; TEIXEIRA, D. C. Physical activity in daily life in physically independent elderly participating in community-based exercise program. Braz J Phys Ther, v. 17, n. 1, jan./feb. 2013. http://dx.doi.org/10.1590/S141335552012005000055

KAGAWA, C.A.; CORRENTE, J. E. Análise da capacidade funcional em idosos do município de Avaré-SP: fatores associados. Rev Bras Geriatr Gerontol. v.18, n. 3, p. 577-86, 2015. http://dx.doi.org/10.1590/18099823.2015.14140.

KONG, K.; LEE J. Temporal recovery of activities of daily living in the first year after ischemic stroke: a prospective study of patients admitted to a rehabilitation unit. NeuroRehabilitation, v. 35, n. 2, p. 221-6, jan. 2014. https://doi.org/10.3233/NRE-141110.

KUMAR, A.; CARPENTER, H.; MORRIS, R.; ILIFFE, S.; KENDRICK, D. Which factors are associated with fear of falling in community-dwelling older people? Age Ageing, v. 43, n. 1, p. 76-84, jan, 2014. https://doi.org/ 10.1093/ageing/aft154.

MINOSSO, J. S. M; AMENDOLA, F.; ALVARENGA, M. R. M.; OLIVEIRA, M. A. C. Validação, no Brasil, do Índice de Barthel em idosos atendidos em ambulatórios. Acta paul. enferm., São Paulo , v. 23, n. 2, p. 218 223, Apr. 2010. http://dx.doi.org/10.1590/S0103-21002010000200011

MORONE, G.; PAOLUCCI, S.; IOSA, M. In What Daily Activities Do Patients Achieve Independence after Stroke? J Stroke Cerebrovasc Dis, v. 24, n. 8, p. 1931-7, aug. 2015. https://doi.org/10.1016/j.jstrokecerebrovasdis.2015.05.006.

MUKA, T,; IMO, D.; JASPERS, L.; COLPANI, V.; CHAKER, L.; van der LEE, S. J.; MENDIS, S.; CHOWDHURY, R.; BRAMER, W. M.; FALLA, A.; PAZOKI, R.; FRANCO, O. H. The global impact of non-communicable diseases on healthcare spending and national income: a systematic review. Eur $\mathbf{J}$ Epidemiol, v. 30, n. 4, p. 251-77, apr 2015. https://doi.org/10.1007/s10654-014-9984-2.

NATIONAL NETWORK CARE CONTINUUM INTEGRATED. Decree-Law No. 101/2006, of June 6 Mundo da Saúde, v. 37, n. 1, p. 105-118, jan.-mar. 2013. Disponível em < $\mathrm{http} / / /$ bvsms.saude.gov.br/bvs/artigos/mundo_saude/rede_nacional_cuidados_continuados_integrados.pdf $>$. Acessado em: 15 dez. 2017.

SCHMIDT, M. I.; DUNCAN, B. B.; SILVA, G. A.; MENEZES, A. M.; MONTEIRO, C. A.; BARRETO, S. M.; CHOR, D., MENESES, P. R. Chronic non-communicable diseases in Brazil: burden and current challenges. Lancet, v. 377, n. 9781, p. 1949-61, jun. 2011. https://doi.org/10.1016/S0140-6736(11)60135-9.

STHAL, H. C.; BERTI, H. W.; PALHARES, V. C. Grau de dependência de idosos hospitalizados para realização das atividades básicas da vida diária. Texto Contexto - Enferm, Florianópolis, v. 20, n. 1, p. 59-67, jan-mar. 2011. http://dx.doi.org/10.1590/S0104-07072011000100007. 
STUCK, A. E.; WALTHERT, J. M.; NIKOLAUS, T.; BÜLA, C. J.; HOHMANN, C.; BECK, J. C. Risk factors for functional status decline in community-living elderly people: a systematic literature review. Soc Sci Med, v. 48, n. 4, p. 445-69, feb. 1999. https://doi.org/10.1016/S0277-9536(98)00370-0

VOSECKOVA, A.; TRUHLAROVA, Z.; LEVICKA, J.; KLIMOVA, B.; KUCA, K. Application of salutogenic concept in social work with diabetic patients. Soc Work Health Care, v. 56, n. 4, p. 244-259, apr. 2017. https://doi.org/10.1080/00981389.2016.1265635.

WHO. World Health Organization. The International Classification of Functioning, Disability and Health (ICF) 2001. Geneva: World Health Organization; 2001. http://www.who.int/classifications/icf/en/).

WHO. World Health Organization. Global status report on noncommunicable diseases 2014. Geneva: World Health Organization; 2014. http://www.who.int/nmh/publications/ncd-status-report-2014/en/

WHO. World Health Organization. Tackling NCDs: 'Best buys' and other recommended interventions for the prevention and control of noncommunicable diseases. Geneva: World Health Organization; 2017. http://apps.who.int/iris/bitstream/handle/10665/259232/WHO-NMH-NVI-17.9-eng.pdf 